\title{
PHARMACIST'S STRATEGIES IN TREATING ASTHMA BRONCHIALE OUTPATIEN
}

\author{
Amelia Lorensia ${ }^{1)}$, Endang Wahjuningsih' ${ }^{1)}$, Benny Canggih' ${ }^{2)}$, Natalia Lisiska ${ }^{2)}$ \\ Lecturer, Pharmacy Faculty of Surabaya University, Surabaya, Indonesia ${ }^{1)}$, \\ Student, Pharmacy Faculty of Surabaya University, Surabaya, Indonesia ${ }^{2)}$ \\ e-mail : amelia.lorensia@gmail.com
}

\begin{abstract}
ABSTRAK
Asma adalah salah satu masalah kesehatan utama dunia. Gejala asma yang sebenarnya dapat diobati dan dikendalikan sehingga mencegah serangan yang serius. Apoteker perlu memainkan perannya dalam pharmaceutical care (pelayanan kefarmasian) yang bertujuan untuk menemukan sistem perawatan kesehatan yang diperlukan untuk meningkatkan nilai terapi obat kompleks dan signifikan obat morbiditas dan mortalitas terkait, berfungsi untuk meningkatkan hasil farmakoterapi dan kualitas hidup pasien asma. Persepsi pasien terhadap kesehatan dan penyakit terkait juga sangat penting utnuk efektifitas perawatan farmasi. Penelitian ini bertujuan untuk mempelajari peran apoteker dalam perawatan farmasi dalam pengobatan rawat jalan asma bronkial. Jenis penelitian ini adalah cross-sectional. Jumlah responden 22 Pasien. Data diperoleh dengan wawancara langsung untuk mengumpulkan data, disertai dengan pengamatan dari pasien. Hasil: jumlah drug-related problems (DRPs) adalah 20 kasus (problem based) dan 23 kasus (caused-based). Kelas obat yang menyebabkan DRPs terbanyak adalah beta-2 agonis. Pesrsepsi subjektif dari gejala yang dialami oleh sebagian besar pasien dengan asma adalah : sesak napas (100\%), suara mengi (90\%), kelelahan dan kesulitan tidur (85\%). Aspek kognitif penyakit yang dirasakan oleh pasien mengenai identitas, penyebab penyakit dan menyembuhkan atau mengendalikan penyakit adalah benar, tetapi tentang konsekuensi dan timeline masih kurang. Penelitian ini menunjukkan bahwa peran apoteker dalam perawatan farmasi pada pasien asma rawat jalan memiliki sifat konseling langsung ke pasien dan pemantauan. Pemantauan pasien secara teratur dan analisis terjadinya DRPs untuk membantu pasien mendapatkan pengobatan yang efektif, aman dan rasional.
\end{abstract}

Kata kunci: asma, pelayanan kefarmasian, drug-related problems, persepsi sakit

\begin{abstract}
Asthma is one of the major health problems in the world. Actual asthma symptoms can be treated and controlled, so that most patients can prevent the onset of symptoms throughout the day, to prevent a serious attack. Pharmacists play a role in pharmaceutical care that aims to find health care system needed to improve drug therapy of complex and significant value of drug-related morbidity and mortality, functions to improve pharmacotherapy outcomes and quality of life of patients with asthma. The patient's belief about health and illness and related behaviors are also very important to the effectiveness of pharmaceutical care. Objective research to study the role of pharmacists in pharmaceutical care in the treatment of outpatient asthma bronchiale. The type of study was cross-sectional. The number of respondents recruited was 22 patients. In this study data were obtained by direct interview using a form of data collection, accompanied by observations of the patients. Result research Patients involved in this study were 22. The total numbers of DRPs were 20 cases (problem-based) and 23 cases
\end{abstract}


(cause-based). The class of drugs causing most DRPs was beta- 2 agonist. The subjective perceptions of symptoms experienced by the majority of patients with asthma were: shortness of breath $(100 \%)$, wheezing sound (90\%), fatigue and difficulty sleeping $(85 \%)$. The cognitive aspect of illness perceived by the patients regarding identity, cause of illness and cure or control was correct, but those concerning consequences and timeline were still lacking. This study demonstrates that the role of pharmacists in pharmaceutical care in ambulatory asthma patients has a nature of direct counseling to patients and monitoring. Monitoring of patients on a regular basis and analysis of the occurrence of drug-related problems might help the patients to get effective, safe and rational treatment.

Keywords: asthma, pharmaceutical care, drug related problems, illness perception

\section{INTRODUCTION}

Asthma is still one of the major health problems in the world [1]. Although new drugs and evidence-based guidelines have been developed in recent years, but no major changes in morbidity and mortality asma [2]. Guidelines for the treatment of asthma recommend the involvement of patients greater role in their treatment [3].

According to data from WHO (World Health Organization), at 15 million people experience disability-adjusted life years (DALYs) annually due to asthma, representing $1 \%$ of the total disease burden global [1]. SKRT (Survei Kesehatan Rumah Tangga) also states that asthma including 10 major causes of morbidity and mortality in Indonesia.

In 1986, SKRT found that asthma and COPD (chronic obstructive pulmonary disease) ranked $5^{\text {th }}$ out of 10 causes of morbidity. SKRT's data in 1992, asthma and COPD is the $4^{\text {th }}$ leading cause of death (mortality). While in 1995, the prevalence of asthma of 13/1000, compared with chronic bronchitis and obstructive lung 11/1000 2/1000 [4].

The National Asthma Education and Prevention Program (NAEPP) defines asthma as a chronic inflammatory disorder of the airways in which many cells and cellular elements play a role. In individuals with asthma, inflammation causes recurrent episodes of wheezing, shortness, chest thightness, and cough [1].

Actual asthma symptoms can be treated and controlled, so that most patients can prevent the onset of symptoms throughout the day, to prevent a serious attack [4]. In the patients with asthma treatment, pharmacists play a role in pharmaceutical care. Elkhansa Abdelhamid et al. research on pharmaceutical care in hospitals of patients with asthma, in the Shaab Teaching Hospital in Sudan. In this study using a prospective method, randomized sampling, controlled study involving 100 patients with asthma (the intervention group (60) and control group (40)), the study concluded that the intervention of the pharmacist in pharmaceutical care can have a positive effect on asthma-related outcomes on patient [5].

The practice of pharmaceutical care aims to find health care system needed to improve drug therapy of complex and significant value of drug-related morbidity and mortality caused by the drug used [6]. Therefore, the introduction of pharmaceutical care is needed in developing countries to increase the resolution of problems drug related (drug related problems / DRPs) [7]. 
DRPs can lead to unwanted outcomes that increase morbidity and mortality. Bootman (2007) examined outcomes in outpatient DRPs caused in the United States. Results of outcomes caused DRPs found that patients who have failed therapy $(23 \%)$, patients who are experiencing new medical problems $(11 \%)$, patients who have failed therapy and new medical problems (7\%), patients receiving drug therapy at least of experience one DRPs $(>40 \%)$ [7]. Pharmaceutical care can be an appropriate strategy to prevent and control morbidity and mortality caused DRPs [8].

Pharmaceutical care functions to improve pharmacotherapy outcomes and quality of life of patients. Therefore, pharmacists need to carry out its role in pharmaceutical care to assess the presence of drug-related problems (DRPs) in the treatment of patients [9] with identifying and correcting potential causes that caused the problem in pharmacotherapy $[10,11]$ to prevent and control drug-related morbidity and mortalitas [6].

Procedures to identify and intervene in actual and potential DRPs, done with the awareness that all the drug at risk of DRPs is an important element of drug therapy and can contribute to reducing morbidity and mortality. Optimization of therapy by preventing DRPs will affect health care costs, potentially saving lives and improving quality of life pasien [12].

Self-management of asthma can reduce the incidence and improve the quality of life of pasien $[13,14]$. The ability of selfmanagement should be developed through patient education about asthma therapy by health accuracy. Pharmacists can provide education by providing information on asthma treatment, demonstrate how to use inhaled medications and peak flow meters, helping patients to understand their asthma management plan, and monitor the use of medical treatment [15].

DRPs that have been analyzed data can be used as an illustration in providing CIE (Communications, Information, and Education) in patients with asthma according to the pharmaceutical care. Understanding the patient's belief about health and illness and related behaviors are very important to the effectiveness of pharmaceutical care [16].

In Germany, Schulz et al. conducting a study on 173 patients (intervention group of 101 patients and control groups were 63 patients). Peak flow rate values higher achieved in the intervention group after 6 months, but not at 12 months. However, inhaler technique, medication knowledge, and quality of life was higher in the intervention group after 12 months [2]. Maltese studies report that community pharmacy based asthma education program checkers monitoring has a positive effect on quality of life, peak expiratory flow values, inhalation technique, adherence to therapy and the number of patients who entered the hospital [17].

This research aims not only to know what can happen DRPs in patients with asthma outpatient (patients with asthma who have chronic asthma therapy), and also know the perception of asthma patients to asthma and asthma treatment she had received, including consequences, timeline, personal control, treatment control, identify, concerns, emotions, and illness comprehensibility [18]. So by knowing the DRPs and the perception of asthma patients, it can be used as a strategy for the preparation of an IEC to achieve optimal asthma treatment. 


\section{METHOD}

This research method is descriptive analytic study which is a non experimental cross sectional (for drug-related data collection problems (DRPs) outpatients at the hospital) that is the way data is collected at a single time point only.

\section{Identification Research Variable}

Depending variable consists of drug-related problems (DRPs), the causes of DRPs and the perceptions of patients to disease and asthma treatment. Free variables consist of: a history of previous illness, the results of laboratory tests, drugs therapy. Controlled variables consisted of asthma patients who undergo outpatient treatment in respiratory polychlinic Adi Husada Undaan Wetan Hospital, Surabaya.

\section{Population and Sample}

The study population was patients with asthma who are undergoing outpatient treatment and meet the criteria for research, in hospitals (in clinical medicine) during the study.

Samples are asthma patients who are undergoing outpatient treatment and fulfilled the criteria, can be found by investigators and were willing to be a sample of research, in hospitals (in clinical medicine) during the study.

Inclusion criteria for the outpatient sample: (1) Patients asthma with aged $\geq 18$ years and came to the polychlinic in Adi Husada Undaan Wetan Hospital to undergo outpatient treatment during the study, (2) Patients who are willing to participate in the research sample. Criteria exclusion (for the perception of asthma) [18]: women pregnant/lactating, patients who have other respiratory diseases (such as chronic obstructive pulmonary disease/COPD, emphysema, tuberculosis/TB), patients with mental disorders, patients with hearing loss.

\section{Data Collection}

In this study data were obtained by direct interview using a form of data collection, accompanied by observations of the patient.

\section{RESULT AND DISCUSSION}

\section{RESULT}

Research to obtain data of patients with asthma outpatient (chronic asthma) was undertaken during November $16^{\text {th }}, 2010$ until January $15^{\text {th }} ， 2011$ against asthma patients who undergo outpatient treatment at the Hospital. The number of respondents (sample) collected by 22 people, of the total population of the study as many as 23 people in which researchers found when respondents came to the clinic treatment of disease in the hospital. One person cannot be used as a sample of the research because it is not treated at the clinic when researchers are not in place. The sex of the study sample consisted of 10 male sex (45\%) and 12 are female (55\%). Age of the study sample varied with sample minimum age 19 years and maximum age of 70 years of research samples. The average age of the study sample was 35,10 years. Of the 22 samples studies suffer from asthma $45.44 \%$ between 11-20 years; $22.73 \%$ for more than 20 years; $22.73 \%$ between $2-5$ years, $4.55 \%$ between $6-10$ years, and $4.55 \%$ for less than one year. 
Table 1. The types of DRPs Based on Problems in Sample with Chronic Asthma

\begin{tabular}{|c|c|c|c|c|c|c|}
\hline \multicolumn{2}{|c|}{$\begin{array}{l}\text { Primary Domain of } \\
\text { DRPs based The } \\
\text { Problems }\end{array}$} & \multirow[b]{2}{*}{$\begin{array}{l}\text { Problems } \\
\text { Theophylline as a therapy of } \\
\text { chronic asthma. Data from } \\
\text { theophylline effectiveness as } \\
\text { long-term controller is still } \\
\text { lacking, and still have a small } \\
\text { effect as the controller's first } \\
\text { choice. And its effectiveness is } \\
\text { smaller than LABA (long acting } \\
\text { B2 agonist), so theophylline used } \\
\text { as additional therapy when } \\
\text { symptoms of asthma has not been } \\
\text { controlled with inhaled } \\
\text { glucocorticosteroids. }\end{array}$} & \multirow{2}{*}{$\begin{array}{l}\text { Recomendation } \\
\text { Discuss with doctor } \\
\text { about appropriate } \\
\text { treatment in } \\
\text { accordance with the } \\
\text { guidelines. }\end{array}$} & \multicolumn{2}{|c|}{ Frequency } & \multirow{2}{*}{$\begin{array}{l}\text { Percent } \\
(\%) \\
25\end{array}$} \\
\hline $\begin{array}{l}\text { Treatment } \\
\text { effectiveness }\end{array}$ & $\begin{array}{l}\text { Effect of } \\
\text { drug } \\
\text { treatment } \\
\text { not } \\
\text { optimal }\end{array}$ & & & 4 & 5 & \\
\hline & & $\begin{array}{l}\text { The use of NSAIDs (ketoprofen) } \\
\text { in patients with asthma can cause } \\
\text { asthma exacerbations, although } \\
\text { it's a individual effect. }\end{array}$ & & 1 & & \\
\hline & $\begin{array}{l}\text { Untreated } \\
\text { indication }\end{array}$ & $\begin{array}{l}\text { Not getting treatment as a } \\
\text { reliever. Reliever used in all } \\
\text { stage of chronic asthma therapy } \\
\text { as a rapid bronchoconstriction in } \\
\text { acute symptoms, so it's needed } \\
\text { all patients with asthma on } \\
\text { chronic asthma therapy. }\end{array}$ & & 1 & 5 & 25 \\
\hline & & $\begin{array}{l}\text { Not getting antiplatelet in patients } \\
\text { with hypertension. Antiplatelet as } \\
\text { primary prevention to prevent } \\
\text { cardiovascular risk, including } \\
\text { people with age> } 40 \text { years or who } \\
\text { have additional risk factors } \\
\text { (family history of CVD, } \\
\text { hypertension, smoking, } \\
\text { dyslipidemia, or albuminuria. }\end{array}$ & & 2 & & \\
\hline & & $\begin{array}{l}\text { Not getting lipid drug (Statins) in } \\
\text { patients with hypertension, in } \\
\text { which statins work to CVD } \\
\text { outcomes in patients. In patients } \\
\text { with chronic diseases such as } \\
\text { diabetes mellitus also have an } \\
\text { increased lipid abnormalities, } \\
\text { which can contribute to the risk } \\
\text { factors of CVD. }\end{array}$ & & 2 & & \\
\hline
\end{tabular}


Table 1. The types of DRPs Based on Problems in Sample with Chronic Asthma (Continue)

\begin{tabular}{|c|c|c|c|c|c|c|}
\hline \multicolumn{2}{|c|}{$\begin{array}{l}\text { Primary Domain of } \\
\text { DRPs based The } \\
\text { Problems }\end{array}$} & Problems & Recomendation & \multicolumn{2}{|c|}{ Frequency } & $\begin{array}{c}\text { Percen } \\
(\%) \\
\end{array}$ \\
\hline $\begin{array}{l}\text { Adverse } \\
\text { Reaction }\end{array}$ & $\begin{array}{l}\text { Adverse } \\
\text { drug } \\
\text { event } \\
\text { (non- } \\
\text { allergic) }\end{array}$ & $\begin{array}{l}\text { Fatigue because of losartan } \\
\text { (ARB). Losartan, one of which is } \\
\text { used by asthma patients in this } \\
\text { study, serves as a less risky } \\
\text { antihypertensive ARBs } \\
\text { (Angiotensin Receptor Blocker). } \\
\text { Is a non-peptide antagonist } \\
\text { losartan, competitive and selective } \\
\text { angiotensin II receptor. } \\
\text { Mechanism of action of losartan is } \\
\text { a reversible binding with AT1 and } \\
\text { AT2 receptors and by blocking } \\
\text { the effects of vasoconstriction and } \\
\text { aldosterone secretion } \\
\text { angiotensin II. Fatigue arising } \\
\text { from the use of losartan is } \\
\text { possible because the effect of } \\
\text { inhibition of aldosterone } \\
\text { secretion. If too large decreases } \\
\text { the secretion of aldosterone, fluid } \\
\text { and electrolyte balance will be } \\
\text { disturbed and manifestations that } \\
\text { often appear among other tired. }\end{array}$ & $\begin{array}{l}\text { Conduct regular } \\
\text { monitoring and } \\
\text { implementation of the } \\
\text { CIE to the patient. }\end{array}$ & 1 & 3 & \\
\hline & & $\begin{array}{l}\text { Dizziness due to the use of } \\
\text { salbutamol (short-acting B2 } \\
\text { agonist). } \\
\text { ADR in the form of dizziness } \\
\text { caused by salbutamol likely } \\
\text { caused by smooth muscle relaxing } \\
\text { effect of salbutamol. Relaxation } \\
\text { effect arises because } \beta 2 \text { receptor } \\
\text { stimulation. Receptor } \beta 2 \text { not only } \\
\text { found in the respiratory tract but } \\
\text { also found in bone and muscle } \\
\text { blood vessels of the heart. } \\
\text { Excessive stimulation of } \beta 2 \\
\text { receptors (mainly located in } \\
\text { vascular smooth muscle of the } \\
\text { heart) will cause vasodilating } \\
\text { blood vessels in the heart that can } \\
\text { cause a decline in blood pressure. } \\
\text { Manifestations that arise from } \\
\text { decreased blood pressure is one of } \\
\text { them is a headache. }\end{array}$ & & 1 & & \\
\hline & & $\begin{array}{l}\text { Dry mouth because of salbutamol } \\
\text { (short-acting B2 agonist) }\end{array}$ & & 1 & & \\
\hline
\end{tabular}


Table 1. The types of DRPs Based on Problems in Sample with Chronic Asthma (Continue)

\begin{tabular}{|c|c|c|c|c|c|c|}
\hline \multicolumn{2}{|c|}{$\begin{array}{c}\text { Primary Domain of } \\
\text { DRPs based The } \\
\text { Problems } \\
\end{array}$} & \multirow[b]{2}{*}{$\begin{array}{l}\text { Problems } \\
\text { Formoterol (long acting B2 } \\
\text { agonist) was used as a reliever. } \\
\text { Salbutamol is used in the } \\
\text { treatment of asthma because of } \\
\text { the effects of rapid } \\
\text { bronchodilating, making it } \\
\text { suitable for use in the event of an } \\
\text { acute attack and is the drug of } \\
\text { choice for asthma attacks. }\end{array}$} & \multirow{2}{*}{$\begin{array}{l}\text { Recomendation } \\
\text { Discuss with doctor } \\
\text { about appropriate } \\
\text { treatment in } \\
\text { accordance with the } \\
\text { guidelines. }\end{array}$} & \multicolumn{2}{|c|}{ Frequency } & \multirow{2}{*}{$\begin{array}{c}\text { Percent } \\
(\%)\end{array}$} \\
\hline $\begin{array}{l}\text { Treatment } \\
\text { Costs }\end{array}$ & $\begin{array}{l}\text { Drug } \\
\text { treatment } \\
\text { more } \\
\text { costly } \\
\text { than } \\
\text { necessary }\end{array}$ & & & 3 & 3 & \\
\hline \multirow{3}{*}{\multicolumn{2}{|c|}{ Others }} & $\begin{array}{l}\text { Drug interactions between } \\
\text { Diltiazem (calcium channel } \\
\text { blocker) and Theofilin (Potential) }\end{array}$ & $\begin{array}{l}\text { Perform regular } \\
\text { monitoring of } \\
\text { patients. }\end{array}$ & 1 & 4 & 20 \\
\hline & & $\begin{array}{l}\text { Drug interactions between } \\
\text { Salbutamol (short acting B2 } \\
\text { agonis) dan Theofilin (Potensial) }\end{array}$ & & 2 & & \\
\hline & & $\begin{array}{l}\text { Salbutamol (short-acting B2 } \\
\text { agonist) as a reliever that is used } \\
\text { is the oral form (Actual) }\end{array}$ & & 1 & & \\
\hline \multicolumn{2}{|c|}{ Total } & & & & 20 & 100 \\
\hline
\end{tabular}

A controlled asthma is asthma in which symptoms of shortness of breath, wheezing, coughing, etc. can be removed so as not to interfere with activity so that patients can move normally. Spirometry and Peak Flow Meter can help to diagnose asthma and assess the control asma [1, 19]. Based on interviews with outpatient asthma patients, $45,45 \%$ claim to be obedient in taking the medicine according to doctor's instructions so that his asthma control, $9,09 \%$ said no obedient in using the medicine so often symptoms occur, while $45,05 \%$ did not know.

Of 22 samples of the study patients who say they adhere to the use of medication as many as 10 peoples $(45.45 \%)$, and 2 $(9.09 \%)$ said they had low adherence (nonadherent) to the treatment. Stage asthma based on outpatient treatment received by patients when interviewed by investigators, according to Global Initiative for Asthma in 2009. It is shown variations in the sample experienced asthma stage of research. Most of the research sample is at stage $1(68,18 \%)$. Followed by in stage 3 $(13,64 \%)$, in stage $2(9,09 \%)$, unknown $(9,09 \%)$, and in stage 4 and $5(0 \%)$. Two study samples were classified as stage unknown because of asthma medication used could not be classified under the Global Initiative for Asthma in 2009.

Third ADRs caused by salbutamol and losartan are said to be actual because it appears the clinical manifestations in patients with asthma. To support this allegation Naranjo scale used to ascertain whether the clinical manifestations that emerges is the ADRs or not. From the calculation Naranjo scale, both drugs provide the same value of 4 that are interpreted as possible ADRs (possible ADRs). The evidence to support this allegation was not so strong because of limitations in this study is the limited amount of research samples and data obtained based on the patient's memory so 
that there are some data that cannot be obtained.

According to Odgen (2007), cognitive perception of pain is a picture of the patient against disease by identifying five dimensions [24] the identity, consequences, cause of illness, timeline, and cure or control. The results showed that the subjective perception of symptoms experienced by the majority of patients with asthma are: shortness of breath (100\%), wheezing sound arises (90\%), fatigue and difficulty sleeping (85\%). According to Elaine N. Marieb (2004), if there is disorder of the airways or excess mucus production can lead to wheezing sounds (Whistling sound), this shows the difficulty in breathing and wheezing sound associated with asthma. If there is difficulty in breathing, the body's cells deficient supply of oxygen, which causes the body becomes tired. Sore throat have also been associated with disease asma [25].

Patient Perceptions Regarding Impact and Results of Diseases (Consequences) showed that most patients $(65 \%)$ answered asthma affects the activity. In fact, patients with asthma do have limitations in activity. Therefore, if it has been known to any activity which may cause asthma, patients should be given counseling prior to taking the medicine as prevention of attacks asma [1]. If patients rarely take medicine, using inhalers in the wrong way, and improper dosage can trigger asthma attack so as to provide impact and results deteriorate if not treated immediately. Thus, should immediately be referred to the hospital.

Patient Perceptions Regarding the causes of disease (Cause of Illness) showed that the three top factors that cause disease in a row their asthma is heredity, environmental pollution, and patterns/eating habits. Heredity/genetics is a family disease history of patients who had suffered from asthma. Heredity/genetics it is one of the dominant causes of asthma. Environmental pollution consisting themselves of cigarette smoke, motor vehicle fumes, factory smoke, and free radicals is one of the causes of the attacks asma [1]. Perceptions of Patients Against Asthma How Long Will Lasts (Timeline) indicates that only a few patients ( 8 of 20 people) who know the disease of asthma will last forever. $10 \%$ of patients respond within days and $20 \%$ of patients respond within a few years of his asthma disease will be cured. Many of them do not yet know that his asthma disease can occur at any time and not unexpected. The rest are those who do not know/doubtful (30\%) in the answer. Asthma do not know the word "cured", because it is not curable and can arise at anytime [1].

Treatment for asthma therapy are classified as a reliever or controller. Reliever is a medication that is used when necessary that is fast to reduce bronchoconstriction and reduce acute symptoms that accompany it. While the Controller is a medication that is used daily in the long term to keep asthma under clinical control over the effect of anti inflamation [1]. Perceptions Regarding the Treatment of Patients Can Help The disease (Cure or Control) showed that most patients ( 15 of 20 patients) said the disease asthma is controlled.

There is a patient believes that the medication used to help overcome his asthma attacks (15 of 20 people). While the data indicated the majority of patients experience frequent asthma symptoms in 12 times a month (10 of 20 people). This is one feature of control asthma [1]. 
Table 1. The types of DRPs Based on Problems in Sample with Chronic Asthma

\begin{tabular}{|c|c|c|c|c|c|c|}
\hline \multicolumn{2}{|c|}{$\begin{array}{l}\text { Primary Domain of } \\
\text { DRPs based The } \\
\text { Problems }\end{array}$} & \multirow[b]{2}{*}{$\begin{array}{l}\text { Problems } \\
\text { Theophylline as a therapy of } \\
\text { chronic asthma. Data from } \\
\text { theophylline effectiveness as } \\
\text { long-term controller is still } \\
\text { lacking, and still have a small } \\
\text { effect as the controller's first } \\
\text { choice. And its effectiveness is } \\
\text { smaller than LABA (long acting } \\
\text { B2 agonist), so theophylline used } \\
\text { as additional therapy when } \\
\text { symptoms of asthma has not been } \\
\text { controlled with inhaled } \\
\text { glucocorticosteroids. }\end{array}$} & \multirow{2}{*}{$\begin{array}{l}\text { Recomendation } \\
\text { Discuss with doctor } \\
\text { about appropriate } \\
\text { treatment in } \\
\text { accordance with the } \\
\text { guidelines. }\end{array}$} & \multicolumn{2}{|c|}{ Frequency } & \multirow{2}{*}{$\begin{array}{l}\text { Percent } \\
(\%)\end{array}$} \\
\hline $\begin{array}{l}\text { Treatment } \\
\text { effectiveness }\end{array}$ & $\begin{array}{l}\text { Effect of } \\
\text { drug } \\
\text { treatment } \\
\text { not } \\
\text { optimal }\end{array}$ & & & 4 & 5 & \\
\hline & & $\begin{array}{l}\text { The use of NSAIDs (ketoprofen) } \\
\text { in patients with asthma can cause } \\
\text { asthma exacerbations, although } \\
\text { it's a individual effect. }\end{array}$ & & 1 & & \\
\hline & $\begin{array}{l}\text { Untreated } \\
\text { indication }\end{array}$ & $\begin{array}{l}\text { Not getting treatment as a } \\
\text { reliever. Reliever used in all } \\
\text { stage of chronic asthma therapy } \\
\text { as a rapid bronchoconstriction in } \\
\text { acute symptoms, so it's needed } \\
\text { all patients with asthma on } \\
\text { chronic asthma therapy. }\end{array}$ & & 1 & 5 & 25 \\
\hline & & $\begin{array}{l}\text { Not getting antiplatelet in patients } \\
\text { with hypertension. Antiplatelet as } \\
\text { primary prevention to prevent } \\
\text { cardiovascular risk, including } \\
\text { people with age> } 40 \text { years or who } \\
\text { have additional risk factors } \\
\text { (family history of CVD, } \\
\text { hypertension, smoking, } \\
\text { dyslipidemia, or albuminuria. }\end{array}$ & & 2 & & \\
\hline & & $\begin{array}{l}\text { Not getting lipid drug (Statins) in } \\
\text { patients with hypertension, in } \\
\text { which statins work to CVD } \\
\text { outcomes in patients. In patients } \\
\text { with chronic diseases such as } \\
\text { diabetes mellitus also have an } \\
\text { increased lipid abnormalities, } \\
\text { which can contribute to the risk } \\
\text { factors of CVD. }\end{array}$ & & 2 & & \\
\hline
\end{tabular}


Table 1. The types of DRPs Based on Problems in Sample with Chronic Asthma (Continue)

\begin{tabular}{|c|c|c|c|c|c|c|}
\hline \multicolumn{2}{|c|}{$\begin{array}{l}\text { Primary Domain of } \\
\text { DRPs based The } \\
\text { Problems }\end{array}$} & Problems & Recomendation & \multicolumn{2}{|c|}{ Frequency } & $\begin{array}{c}\text { Percen } \\
(\%) \\
\end{array}$ \\
\hline $\begin{array}{l}\text { Adverse } \\
\text { Reaction }\end{array}$ & $\begin{array}{l}\text { Adverse } \\
\text { drug } \\
\text { event } \\
\text { (non- } \\
\text { allergic) }\end{array}$ & $\begin{array}{l}\text { Fatigue because of losartan } \\
\text { (ARB). Losartan, one of which is } \\
\text { used by asthma patients in this } \\
\text { study, serves as a less risky } \\
\text { antihypertensive ARBs } \\
\text { (Angiotensin Receptor Blocker). } \\
\text { Is a non-peptide antagonist } \\
\text { losartan, competitive and selective } \\
\text { angiotensin II receptor. } \\
\text { Mechanism of action of losartan is } \\
\text { a reversible binding with AT1 and } \\
\text { AT2 receptors and by blocking } \\
\text { the effects of vasoconstriction and } \\
\text { aldosterone secretion } \\
\text { angiotensin II. Fatigue arising } \\
\text { from the use of losartan is } \\
\text { possible because the effect of } \\
\text { inhibition of aldosterone } \\
\text { secretion. If too large decreases } \\
\text { the secretion of aldosterone, fluid } \\
\text { and electrolyte balance will be } \\
\text { disturbed and manifestations that } \\
\text { often appear among other tired. }\end{array}$ & $\begin{array}{l}\text { Conduct regular } \\
\text { monitoring and } \\
\text { implementation of the } \\
\text { CIE to the patient. }\end{array}$ & 1 & 3 & \\
\hline & & $\begin{array}{l}\text { Dizziness due to the use of } \\
\text { salbutamol (short-acting B2 } \\
\text { agonist). } \\
\text { ADR in the form of dizziness } \\
\text { caused by salbutamol likely } \\
\text { caused by smooth muscle relaxing } \\
\text { effect of salbutamol. Relaxation } \\
\text { effect arises because } \beta 2 \text { receptor } \\
\text { stimulation. Receptor } \beta 2 \text { not only } \\
\text { found in the respiratory tract but } \\
\text { also found in bone and muscle } \\
\text { blood vessels of the heart. } \\
\text { Excessive stimulation of } \beta 2 \\
\text { receptors (mainly located in } \\
\text { vascular smooth muscle of the } \\
\text { heart) will cause vasodilating } \\
\text { blood vessels in the heart that can } \\
\text { cause a decline in blood pressure. } \\
\text { Manifestations that arise from } \\
\text { decreased blood pressure is one of } \\
\text { them is a headache. }\end{array}$ & & 1 & & \\
\hline & & $\begin{array}{l}\text { Dry mouth because of salbutamol } \\
\text { (short-acting B2 agonist) }\end{array}$ & & 1 & & \\
\hline
\end{tabular}


Table 1. The types of DRPs Based on Problems in Sample with Chronic Asthma (Continue)

\begin{tabular}{|c|c|c|c|c|c|c|}
\hline \multicolumn{2}{|c|}{$\begin{array}{l}\text { Primary Domain of } \\
\text { DRPs based The } \\
\text { Problems }\end{array}$} & \multirow[b]{2}{*}{$\begin{array}{l}\text { Problems } \\
\text { Formoterol (long acting B2 } \\
\text { agonist) was used as a reliever. } \\
\text { Salbutamol is used in the } \\
\text { treatment of asthma because of } \\
\text { the effects of rapid } \\
\text { bronchodilating, making it } \\
\text { suitable for use in the event of an } \\
\text { acute attack and is the drug of } \\
\text { choice for asthma attacks. }\end{array}$} & \multirow{2}{*}{$\begin{array}{l}\text { Recomendation } \\
\text { Discuss with doctor } \\
\text { about appropriate } \\
\text { treatment in } \\
\text { accordance with the } \\
\text { guidelines. }\end{array}$} & \multicolumn{2}{|c|}{ Frequency } & \multirow{2}{*}{$\begin{array}{c}\begin{array}{c}\text { Percent } \\
(\%)\end{array} \\
15\end{array}$} \\
\hline $\begin{array}{l}\text { Treatment } \\
\text { Costs }\end{array}$ & $\begin{array}{l}\text { Drug } \\
\text { treatment } \\
\text { more } \\
\text { costly } \\
\text { than } \\
\text { necessary }\end{array}$ & & & 3 & 3 & \\
\hline \multirow{3}{*}{\multicolumn{2}{|c|}{ Others }} & $\begin{array}{l}\text { Drug interactions between } \\
\text { Diltiazem (calcium channel } \\
\text { blocker) and Theofilin (Potential) }\end{array}$ & $\begin{array}{l}\text { Perform regular } \\
\text { monitoring of } \\
\text { patients. }\end{array}$ & 1 & 4 & 20 \\
\hline & & $\begin{array}{l}\text { Drug interactions between } \\
\text { Salbutamol (short acting B2 } \\
\text { agonis) dan Theofilin (Potensial) }\end{array}$ & & 2 & & \\
\hline & & $\begin{array}{l}\text { Salbutamol (short-acting B2 } \\
\text { agonist) as a reliever that is used } \\
\text { is the oral form (Actual) }\end{array}$ & & 1 & & \\
\hline \multicolumn{2}{|c|}{ Total } & & & & 20 & 100 \\
\hline
\end{tabular}

\section{DISCUSSION}

Drug groups causing most DRPs are a B2 agonist drug class. B2 agonist serves as a reliever that is used in every stage chronic asthma therapy as a rapid bronchoconstriction in acute symptoms [1], so the reliever (e.g. salbutamol) is required by all asthma patients in chronic asthma therapy. The five dimensions above have revealed a wide range of patient pain perception. Perception of pain patients about identity, cause of illness, and cure or control is right, while on the Consequences and the timeline is still lacking. By knowing a person's perception of his illness, the pharmacist in Pharmaceutical Care to do the counseling, information, and education (CIE) regarding knowledge about asthma and its treatment in order to achieve optimal drug therapies that improve the quality of life of patients. It can also be developed efforts of health promotion strategies and approaches that are good for reducing the number of patients affected by asthma attacks.
The implementation of the necessary pharmaceutical planning to be done on an outpatient:

1. Against other health personnel (doctor) to discuss appropriate treatment in accordance with the Global Initiative for Asthma Guidelines (2009).

2. Implementation of CIE of patientrelated:

a. Compliance with drug use

b. Recognizing the signs of drug side effects of the most mild and common, to the heavy

c. Recognize the patient's asthma control condition

d. Recognizing the triggers for each patient

Need to conduct further research related to pharmaceutical care practice in asthma patients, asthma patients both outpatient and inpatient in order to serve as the evaluation and improvement of pharmaceutical care practice widely. 
Table 2. The types of DRPs Based on Causes in Sample with Chronic Asthma

\begin{tabular}{|c|c|c|c|c|c|c|}
\hline \multicolumn{2}{|c|}{$\begin{array}{c}\text { Primary Domain of } \\
\text { DRPs based The Causes }\end{array}$} & Causes & Recomendation & \multicolumn{2}{|c|}{ Frequency } & \multirow{2}{*}{$\begin{array}{c}\begin{array}{c}\text { Percent } \\
(\%)\end{array} \\
4.35\end{array}$} \\
\hline $\begin{array}{l}\text { Drug } \\
\text { Selection }\end{array}$ & $\begin{array}{l}\text { Innapropiate } \\
\text { drug }\end{array}$ & $\begin{array}{l}\text { The use of NSAIDs } \\
\text { (ketoprofen) in patients with } \\
\text { asthma can cause asthma } \\
\text { exacerbations, } \\
\text { individual behavior. }\end{array}$ & $\begin{array}{l}\text { Discuss with doctor } \\
\text { about appropriate } \\
\text { treatment } \\
\text { accordance with the } \\
\text { guidelines. }\end{array}$ & 1 & 1 & \\
\hline & $\begin{array}{l}\text { Drug } \\
\text { interaction }\end{array}$ & $\begin{array}{l}\text { Drug interactions between } \\
\text { Diltiazem (calcium channel } \\
\text { blocker) and Theofilin } \\
\text { (Potential). Drug interactions } \\
\text { between Diltiazem and } \\
\text { Theophylline potentially occur. } \\
\text { Giving calcium channel } \\
\text { blockers to patients using } \\
\text { theophylline are normally not } \\
\text { caused adverse effect on asthma } \\
\text { control, although the smallest } \\
\text { changes can occur at serum } \\
\text { levels of theophylline. The } \\
\text { mechanism of this interaction is } \\
\text { believed that diltiazem can } \\
\text { decrease theophylline } \\
\text { metabolism in the liver, } \\
\text { possibly by inhibition of P450 } \\
\text { isoenzyme cyctochrome } \\
\text { CYP1A2. }\end{array}$ & $\begin{array}{l}\text { Perform regular } \\
\text { monitoring of } \\
\text { patients. }\end{array}$ & 1 & 3 & 13.04 \\
\hline & & $\begin{array}{l}\text { Drug interactions between } \\
\text { salbutamol (short-acting B2 } \\
\text { agonist) and Theofilin } \\
\text { (Potential). } \\
\text { Drug interactions between } \\
\text { salbutamol (B2Agonis) and } \\
\text { Theofilin potentially occur. The } \\
\text { use of theophylline and beta- } \\
\text { agonists and useful for asthma } \\
\text { therapy, but the potentiation of } \\
\text { adverse effects may occur, the } \\
\text { most serious condition is the } \\
\text { occurrence of hypokalemia and } \\
\text { tachycardia, especially in the } \\
\text { use of high doses of } \\
\text { theophylline. Securities that can } \\
\text { happens is the effect on heart } \\
\text { rate or levels of potassium. B2 } \\
\text { agonists can cause hypokalemia } \\
\text { especially inhen given } \\
\text { parenterally or nebulized. Effect } \\
\text { of potassium level decrease of } \\
\text { drug interactions is not } \\
\text { identified. }\end{array}$ & & 2 & & \\
\hline
\end{tabular}


Table 2. The types of DRPs Based on Causes in Sample with Chronic Asthma (Continue)

\begin{tabular}{|c|c|c|c|c|c|c|}
\hline \multicolumn{2}{|c|}{$\begin{array}{c}\text { Primary Domain of DRPs } \\
\text { based The Causes }\end{array}$} & Causes & Recomendation & \multicolumn{2}{|c|}{ Frequency } & \multirow{4}{*}{\begin{tabular}{|c|}
$\begin{array}{c}\text { Percen } \\
(\%)\end{array}$ \\
30.43
\end{tabular}} \\
\hline & \multirow[t]{3}{*}{$\begin{array}{l}\text { More cost- } \\
\text { effective drug } \\
\text { available }\end{array}$} & $\begin{array}{l}\text { Formoterol (long acting B2 } \\
\text { agonist) was used as a } \\
\text { reliever }\end{array}$ & \multirow{6}{*}{$\begin{array}{l}\text { Discuss with doctor } \\
\text { about appropriate } \\
\text { treatment } \\
\text { accordance with the } \\
\text { guidelines. }\end{array}$} & 1 & \multirow[t]{3}{*}{7} & \\
\hline & & $\begin{array}{l}\text { Theophylline as a therapy of } \\
\text { chronic asthma }\end{array}$ & & 4 & & \\
\hline & & $\begin{array}{l}\text { Fenoterol (long acting B2 } \\
\text { agonist) was used as a } \\
\text { reliever }\end{array}$ & & 2 & & \\
\hline & \multirow{3}{*}{$\begin{array}{l}\text { Synergistic/ } \\
\text { preventive } \\
\text { drug required } \\
\text { and not given }\end{array}$} & $\begin{array}{l}\text { Not getting treatment as a } \\
\text { reliever }\end{array}$ & & 1 & 5 & 21.74 \\
\hline & & $\begin{array}{l}\text { Not getting antiplatelet in } \\
\text { patients with hypertension }\end{array}$ & & 2 & & \\
\hline & & $\begin{array}{l}\text { Not getting your lipid drug } \\
\text { (Statins) in hypertensive } \\
\text { patients }\end{array}$ & & 2 & & \\
\hline \multirow[t]{2}{*}{ Drug Form } & \multirow[t]{2}{*}{$\begin{array}{l}\text { Inappropriate } \\
\text { drug form }\end{array}$} & $\begin{array}{l}\text { Ketoprofen (NSAIDs) are } \\
\text { used as an analgesic. The use } \\
\text { of NSAIDs (ketoprofen) in } \\
\text { patients with asthma can } \\
\text { cause asthma exacerbations, } \\
\text { although the nature } \\
\text { individual. Therefore more } \\
\text { secure if the use of NSAIDs } \\
\text { in the topical form not } \\
\text { systemic. }\end{array}$ & $\begin{array}{l}\text { Discuss with doctor } \\
\text { about appropriate } \\
\text { treatment } \\
\text { accordance with the } \\
\text { guidelines. }\end{array}$ & 1 & 2 & 8.70 \\
\hline & & $\begin{array}{l}\text { Salbutamol (short-acting B2 } \\
\text { agonist) as a reliever that is } \\
\text { used is the oral form. } \\
\text { Salbutamol is indicated for } \\
\text { reliever should not be used in } \\
\text { oral form, but are inhaled. } \\
\text { This is because the benefits } \\
\text { from the use of inhalation, } \\
\text { where the effects to the } \\
\text { respiratory tract will be } \\
\text { faster, and the concentrations } \\
\text { were relatively smaller than } \\
\text { that of systemic side effects } \\
\text { that can be generated } \\
\text { relatively smaller. }\end{array}$ & & 1 & & \\
\hline Patient & \multicolumn{2}{|c|}{ Patients forget to use / consume drugs } & $\begin{array}{l}\text { Implementation of } \\
\text { CIE }\end{array}$ & 2 & 2 & 8.70 \\
\hline \multirow[t]{3}{*}{ Others } & \multicolumn{2}{|c|}{$\begin{array}{l}\text { Fatigue because of losartan } \\
\text { (ARB) (Actual) }\end{array}$} & \multirow{3}{*}{$\begin{array}{l}\text { Conduct regular } \\
\text { monitoring and } \\
\text { implementation of the } \\
\text { CIE to the patient. }\end{array}$} & 1 & 3 & 13.04 \\
\hline & & $\begin{array}{l}\text { ziness due to the use of } \\
\text { utamol (short-acting } \\
\text { aist) (Actual) }\end{array}$ & & 1 & & \\
\hline & & $\begin{array}{l}\text { mouth because of salbutamol } \\
\text { rt-acting B2 agonist) (Actual) }\end{array}$ & & 1 & & \\
\hline \multicolumn{2}{|l|}{ TOTAL } & & & & 23 & 100 \\
\hline
\end{tabular}




\section{CONCLUSION AND SUGGESTION:}

The role of pharmacists in pharmaceutical care in ambulatory asthma patients is a direct counseling to patients and monitoring the use of medications for ambulatory (able to use PMRs/Patient Medication Records). Monitoring treatment of patients on a regular basis and analyze the occurrence of drug-related problems that would/could/have been experienced by patients taking optimal treatment, effective, safe and rational.

\section{ACKNOWLEDGMENTS}

Thanks to dean and associates IN Pharmacy Faculty of Surabaya University, health care teams in Adi Husada Undaan Wetan Hospital, Surabaya and all those who have supported the preparation of this research.

\section{REFERENCE}

1. Global Initiative for Asthma. 2010, Global Strategy for Asthma Management \& Prevention (Update).

2. Schulz, M.; Verheyen, F.; Muhlig, S.; Muller, J.M.; Muhlbauer, K.; Knop-Schneickert, E.; Petermann, F.; \& Bergmann, K.C. 2001, Pharmaceutical care services for asthma patients: a controlled intervention study. $J$. Clin. Pharmacol 41: 668-76.

3. National Asthma Education and Prevention Program. 1997, Guidelines for the diagnosis and management of asthma: Expert Panel Report 2. National Institutes of Health: National Heart, Lung, and Blood Institute.

4. Mangunrejo, H.; Widjaja, A.; Kusumo, D.; Sutoyo.; Yunus, F.; Pradjnaporamita, et al. 2004, Pedoman Diagnosis dan Penatalaksanaan di Indonesia: Asma. Perhimpunan Dokter Paru Indonesia.

5. Abdelhamid, E.; Awad, A.; \& Gismallah, A. 2008, Evaluation of a Hospital PharmacyBased Pharmaceutical Care Services for Asthma Patients, Pharmacy Practice 6(1):2532.
6. Berenguer, B.; La Cassa, C.; de La Matta, M.J.; \& Martin-Calero, M.J. 2004, Pharmaceutical Care: Past, Present and Future. Curr. Pharm .10(31):3931-46.

7. Farris, K.B.; Fernandez-Llimos, F.; \& Benrimoj, S.I. 2005, Pharmaceutical care in community pharmacies: Practice and research from around the world, Ann. Pharmacotherapy 39:539-41.

8. Bootman, L. 2007, Drug Related Morbidity and Mortality Impact of Pharmaceutical Care. World Health Organization: Essensial Medicines and Policy Department (EDM): International Conferences on Improving Use of Medicines (ICIUM) [online] [cited 2010 January 21].

9. American Society of Health-System Pharmacists. 1996, ASHP Guidelines on a Standardized Method for Pharmaceutical Care. Am. J. Health-Syst Pharm. 53: 1713-6.

10. Corelli, R.L.; Kradjan, W.A.; Koda-Kimble, M.A.; Young, L.Y.; Guglielmo, B.J.; \& Alldredge, B.K. 2005, Assessment of Therapy and Pharmaceutical Care. In: Koda-Kimble MA, Young LY, Kradjan WA, Guglielmo BJ, Corelli RL, editors. Applied Therapeutics: The Clinical Use of Drugs. $8^{\text {th }}$ ed. Lippincortt Williams \& Wilkins. Philadelphia; p1.1-1.21.

11. Mill, F.V. 2005, Drug-related Problems: A Cornerstone for Pharmaceutical Care, J.the Malta College of Pharmacy Practice.

12. Blix, H.; Vitkil, K.; Asmund, R.; Tron, M.; Bodil, H.; Piia, P.; et al. 2004, The Majority of Hospitalised Patients Have Drug-Related Problems: Result from A Prospective Study in General Hospitals, Eur. J. Clin. Pharmacology

13. Lahdensuo, A.; Haahtela, T.; Herrala, J.; Kava, T.; Kiviranta, K.; Kuusisto, P.; Perämäki, E.; Poussa, T.; Saarelainen, S.; \& Svahn, T. 1996, Randomised comparison of guided self management and traditional treatment of asthma over one year, BMJ 312:748-52.

14. Beasley, R.; Cushley, M.; \& Holgate, S.T. 1989, A self-management plan in the treatment of adult asthma. Thorax 44:200-4.

15. Gibbs, K.; Small, M.; Asthma. In: Walker, R,; \& Clive, E.; eds. 2003, Clinical Pharmacy and Therapeutics. $3^{\text {rd }}$ ed. Churchill Livingstone; p375-398.

16. Harding, G.; \& Taylor, K. 2002, Social Dimension of Pharmacy: (4) Health, Illness and Seeking Health Care. The Pharmaceutical $J . ; \mathrm{p} 269$.

17. Cordina, M.; McElany, J.C.; \& Hughes, C.M. 2001, Assessment of a community Pharmacy- 
Based program for patients with asthma. Pharmacotherapy 21(10):1196-203.

18. Broadbent E, Petrie KJ, Main J, Weinman J. 2006. The Brief Illness Perception Questionnaire. J. Psychosomatic Research 60: 631- 637.

19. Asthma Management Handbook. 2006, National Asthma Council Australia.

20. Standards of Medical Care in Diabetes: American Diabetes Association. 2009, Diabetes Care 32(1).

21. Lacy, C.; Armstrong, L.; Goldman, M.; \& Lance, L. 2006, Drug Information Handbook: A Comprehensive Resource for all Clinicians and Healthcare Professionals. $14^{\text {th }}$ ed. LexiComp Inc. United States.
22. National Endocrine and Metabolic Diseases Informaton Service: A Service o The Institute of Diabetes and Digestive and Kidney Diseases. 2009, NIH [online] [cited 2010 January 21]. Available from URL:http://www.endocrine.niddk.gov/

23. Baxter Karen, ed. 2006, Stockley's Drug Interactions. $7^{\text {th }}$ ed. Pharmaceutical Press; London p1-11, 697.

24. Ogden, J. 2007, Health Psychology: A textbook 4th ed. London.

25. Marieb, N. 2004, Esssentials of Human Anatomy and Physiology. 4th edition; United States 